- a $\$ 5$ million endowment of the Congressional Fellowship Program by MCI Communications Corporation,

- the funding of a variety of programs on the Bill of Rights for high schools,

- the reinstitution of a "rotator" position at the National Science Foundation for the Political Science Program so that there is an active scholar helping to administer that program,

- the creation of a new course syllabi project so that members, especially new assistant professors, will have access to model syllabi to help structure their courses,

- the publication of the first volume of an oral history of the profession by the University of Kentucky Press, a volume edited by Michael Baer, Malcolm Jewell and Lee Sigelman and jointly funded by APSA's Kirkpatrick Fund and Council and by Pi Sigma Alpha,

- the full implementation of the Minority Identification Project to encourage our best minority undergraduates to go to attend $\mathrm{Ph} . \mathrm{D}$. programs in political science,

- the first short course offered in the new Leading Scholar Series for graduate students, inaugurated this year by Aaron Wildavsky,

- the publication of two other valuable volumes, $A$ Guide to Federal Funding in the Social Sciences and an up-to-date Membership Directory,

- the increase to 90 journals and magazines available to APSA members in the Discount Journal Brochure.

And we are on the verge of getting the diplomatic history series of the State Department a little less politicized and back on track.

Now, what's brewing? PresidentElect Lucius Barker has begun to think about his committee assignments for next year. Here are the committees on which there are vacancies:

The Nominating Committee The Trust and Development Board of Trustees

The Committee on Departmental Services The Editorial Board of $P S$ The Editorial Board of The Political Science Teacher
The Committee on Publications

The Committee on Education

The Kirkpatrick Fund Board of Trustees

The Committee on International Political Science

The Committee on Professional Ethics, Rights and Freedoms

The Research Support Committee

The Status Committees: on Blacks, on Latinos, and on Women

The Endowed Programs Committee

The Award Committees:

Dissertation Awards: Gabriel A. Almond Award, William Anderson Award, Edward S. Corwin Award, Harold D. Lasswell Award, Helen Dwight Reid Award, E. E. Schattschneider Award, Leo Strauss Award, Leonard D. White Award

Paper and Book Awards: Franklin L. Burdette Pi Sigma Alpha Award, Heinz Eulau Award, Ralph J. Bunche Award, Gladys M. Kammerer Award, Victoria Schuck Award, Woodrow Wilson Foundation Award

Career Awards: Carey McWilliams Award, Hubert H. Humphrey Award, John Gaus Lecturer, Benjamin E. Lippincott Award, James Madison Award

Also, as you will see in another part of this issue of $P S$, this year's Nominating Committee will be meeting in February. If you have suggestions, please write Chair Joseph Cooper at 1527 New Hampshire Avenue, N.W., Washington, DC 20036.

We are also working on finding appropriate sites for future Annual Meetings. Deputy Director Robert Hauck is heading this effort. There are very few hotels that can accommodate us anymore. We have been reluctant to move to an impersonal convention center, but we may have to do so.

And we have all of our on-going programs and publications. Here's a partial list:

The American Political Science Review

PS: Political Science \& Politics and The Political Science Teacher

The Personnel Service Newsletter

The APSA Annual Meeting

The APSA Small Research Grant Program

The Minority Graduate Fellowship Program

The Congressional Fellowship Program

The International Exchange Program (with the Chinese, Soviet, Hungarian, and Japanese Political Science Associations)
The International Travel Grant Program The Minority Identification Project

The Credential Referral Service

Dissertation, Book and Career Awards

The Departmental Services Program

The Departmental Services Program for High Schols and for Two-Year Institutions

The Data Collection Program

The Directories of APSA: The Biographical Directory, The Guide to Graduate Study in Political Science, The Directory of Undergraduate Political Science Faculty, The Directory of Membership

The Annual Placement Report

The Publications Program

Project '87

As you can see, there is a tremendous amount of activity at APSA. It is initiated and sustained by APSA members. A combination of the Annual Meeting, the Organized Sections, APSA publications, and the committees provide multiple opportunities to participate in the Association and to have an impact on the profession. If you would like some help in finding a way to participate in APSA, please give me a call or drop me a note. I would love to hear from you.

Sincerely, Catherine E. Rudder

Executive Director

\section{Looking for Something or Some One at the APSA?}

All APSA activities and special projects are governed by a standing committee of the Association. A professional staff member is assigned to each committee to facilitate its work. To help you identify the staff and areas of responsibility we are publishing the following list, and encourage you to contact the appropriate person or persons with your questions and interests:

\section{Full-time Professional Staff}

Catherine Rudder, Executive Director Council and Administrative Committee Trust and Development Committee Nominating Committee

Awards Committee

Congressional Fellowship Program

Ralph Bunche Summer Institute 
Liaison with Consortium of Social Science Associations, American Council of Learned Societies, National Humanities Alliance, and other national organizations

Robert J-P. Hauck, Deputy Director and Director of International Programs

Editor, PS: Political Science \& Politics Annual Meeting and Short Courses Committee on International Programs Liaison with International Political Science Association

Kirkpatrick Fund Board of Trustees Amicus Briefs

Sheilah Mann, Director of

Educational Programs and Co-

Director of Bill of Rights Education

Collaborative

Editor, The Teacher in PS

Committee on the Status of Women

Departmental Services Program

Education Committee

Publications Committee

Endowed Programs Committee

Michael Brintnall, Director of

Professional Affairs

Committee on Professional Ethics, Rights and Freedoms

Ad Hoc Committee on the Status of Gay and Lesbian Political Scientists

APSA Organized Sections

Minority Identification Project

Research Support Committee

Computing and Survey Data on the Profession

\section{Part-Time Professional Staff}

Maurice Woodard, Director of Minority Affairs

Committee on the Status of African Americans

Committee on the Status of Latinos

Ralph Bunche Summer Institute

Minority Graduate Fellowships

Christopher Deering, Academic

Director of the Congressional

Fellowship Program

\section{Washington Annual Meeting Sets Record}

The 87th Annual Meeting of the American Political Science Association again set an attendance record, drawing 5,157 registrants. This exceeds last year's record-setting meeting in San Francisco by 14 percent. A highlight of the meeting was the participation of a delegation from the Japanese Political Science Association. At a time of stirring world events, the meeting aptly explored many themes of pressing interest-including panel discussions of "The USSR: After the Coup" and the plenary discussion addressing the meeting's theme: "America as a Model for the World."

George Quester, University of Maryland, organized this year's highly successful meeting along with the 1991 Program Committee. The Program Committee was composed of many section chairs drawn from representatives nominated by the organized sections, as well as section chairs designated by Quester. Four hundred and sixteen panels were offered, along with 93 panels organized by related groups. The capacity of the Washington Hilton was stretched, though the hotel resourcefully converted sleeping rooms into meeting rooms to accommodate program needs. Nevertheless, panels were also held at sites outside the convention hotel.

Panel attendance averaged 31 people, a slight increase over last year (29). As usual, the most heavily attended sessions were roundtable discussions, with the largest attendance at a discussion organized by Jack Levy, Rutgers University, on

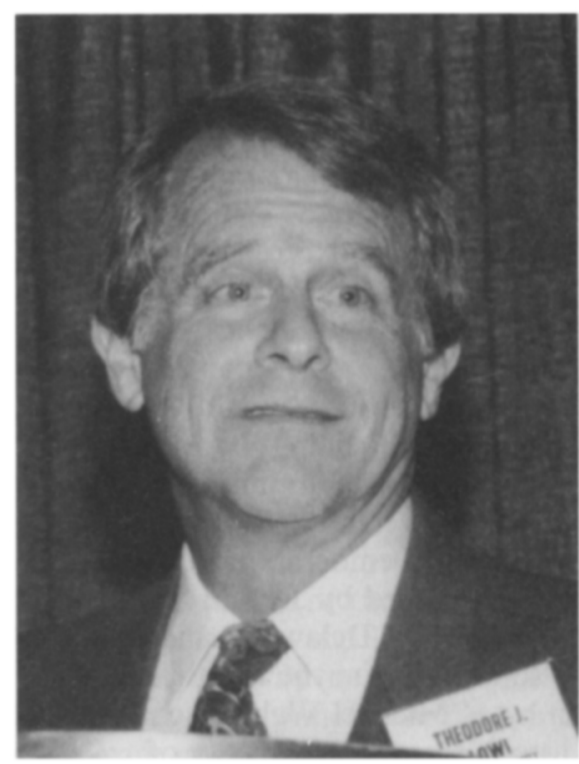

Theodore J. Lowi

the question "Is International War (Still) Becoming Obsolete? Was It Ever?" which drew 226 people.

Roundtables on "William Connolly's Identity/Difference: Democratic Negotiations of Political Paradox" chaired by Thomas Drumm of Amherst College, and on "The Idea of a Political Conception of Justice" chaired by David Johnston of Columbia University also were heavily attended, as was a panel on "Ideas and Politics" chaired by Robert Keohane of Harvard University.

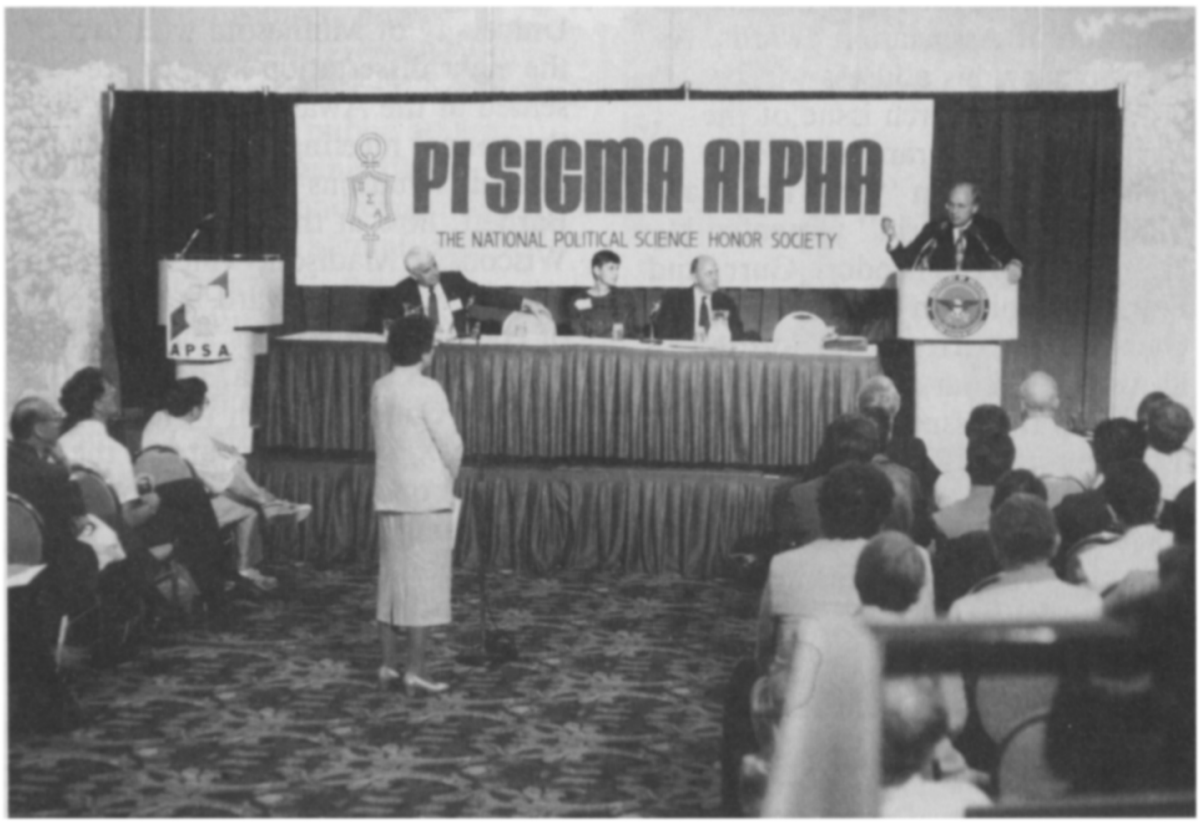

Secretary of Defense Richard Cheney delivers first Pi Sigma Alpha Lecture. 